\title{
The Bright Side of Social Capital: How 'Bridging' Makes Italian Provinces More Innovative
}

Riccardo Crescenzi (SERC, Department of Geography \& Environment, London School of Economics) Luisa Gagliardi (Department of Geography \& Environment, London School of Economics) Marco Percoco (Department of Public Policy and Management, CERTeT, Universita Bocconi)

November 2011 
This work is part of the research programme of the independent UK Spatial Economics Research Centre funded by the Economic and Social Research Council (ESRC), Department for Business, Innovation and Skills (BIS), the Department for Communities and Local Government (CLG), and the Welsh Assembly Government. The support of the funders is acknowledged. The views expressed are those of the authors and do not represent the views of the funders.

(C) R. Crescenzi, L. Gagliardi and M. Percoco, submitted 2011 


\section{The Bright Side of Social Capital: How 'Bridging' Makes Italian Provinces More Innovative \\ Riccardo Crescenzi* \\ Luisa Gagliardi** \\ Marco Percoco****}

November 2011

* SERC, Department of Geography \& Environment, London School of Economics

** Department of Geography \& Environment, London School of Economics

*** Department of Public Policy and Management, CERTeT, Universitá Bocconi

Acknowledgements

The authors are grateful to Sylvie Charlot, Guido De Blasio, Steve Gibbons, Andrés Rodríguez-Pose, Stefano Usai and participants in the ERSA conference 2011 (Barcelona), the EU REAL-CRENos workshop (Cagliari) and Work-in-progress Seminars of the Geography and Environment Department of the London School of Economics for their comments to earlier drafts of this paper. The authors are solely responsible for any errors contained in the paper. 


\begin{abstract}
$\underline{\text { Abstract }}$
Social capital has remained relatively underexplored in innovation literature. Existing studies have failed to reach a consensus on its impact on local innovative performance: some empirical analyses emphasize a positive effect, others speak about a 'dark side' of social capital. This paper aims to fill this gap by shedding new light on the differential role of 'bonding' and 'bridging' social capital. The quantitative analysis of the innovative performance of the Italian provinces shows that social capital is an important predictor of innovative performance after controlling for 'traditional' knowledge inputs (R\&D investments and human capital endowment) and other characteristics of the local economy. However, only 'bridging' social capital - based on weak ties - can be identified as the key driver of the process of innovation while 'bonding' social capital is shown to be negative for innovation. Instrumental variable analysis makes it possible to identify clear causal links between bridging (positive) and bonding (negative) social capital and innovation.
\end{abstract}

JEL Classifications: O31, O33, R15

Keywords: Innovation, social capital, knowledge transfer, regional development 


\section{Introduction}

The concept of social capital has been extensively applied by economists and other social scientists to the analysis of a wide range of phenomena: from economic growth (Knack and Keefer, 1997) and development traps (Woolcock, 1998) to political participation (Di Pasquale and Glaeser, 1999), institutional performance (La Porta et al, 1997) and the spread of secondary education (Goldin and Katz, 2001). However, the analysis of the link between social capital and the genesis of innovation has remained relatively under-explored in 'mainstream' economics literature. Economists of innovation and economic geographers have recently tried to fill this gap but no clear consensus has emerged on the impact of social capital on innovative performance and on the underlying transmission mechanisms (Cohen and Fields, 2000; Hauser, et al. 2007; Kallio et al., 2009; Laursen and Masciarelli, 2007; Patton and Kenney, 2003; Sabatini, 2009; Tura and Harmakorpi 2005).

Existing literature on the social capital-innovation nexus adopts a broad definition of social capital that simultaneously encompasses all its dimensions (associational activities, political participation, institutional thickness and trust). This broad definition has made it difficult not only to empirically operationalise the concept but also to account for the contradictory evidence of its impact on innovative performance (positive in some studies - e.g. Akcomak and ter Weel, 2009 - negative in others - e.g. Florida 2002).

How can Social Capital be operationalised in order to capture its impact on innovative performance? How can its 'bright' and 'dark' sides be reconciled in the analysis of the genesis of innovation? This paper sets out to answer these questions by conceptually 
and empirically disentangling the different roles played by strong and weak ties (Guiso et al., 2010) as the foundations of 'bonding' (based on trust and links between likeminded people in close groups) and 'bridging' (based on trust and networking between heterogeneous groups) social capital (Putnam 2000; Storper, 2005, Rodríguez-Pose and Storper 2006).

In other words, the paper will test the hypothesis that it is not the 'quantity' of social capital per se that matters for innovation but its nature in terms of 'bonding' vs. 'bridging' capabilities: innovation is faster in open societies with a large stock of bridging social capital while bonding social capital is more likely to lead to the generation of closed networks based on the exchange of redundant knowledge, lock-in and cognitive stagnation. In this perspective, both the intensity and typology of network relations among innovative actors matter for innovation. The characteristics of such networks shape the way in which valuable knowledge is exchanged and re-combined (Audretsch and Feldman, 2004), stimulating relational proximity and preventing stagnation and lock-in (Boschma, 2005). In this framework, the impact of social capital on innovation depends not only on the density of the network and on the intensity of the contacts between knowledgeable individuals (total social capital) but also upon the extension of such contacts' "radius of trust" (Fukuyama, 1995). The wider the radius of trust in the network of knowledgeable individuals (i.e. the higher the level of bridging social capital) the greater the likelihood that complementary knowledge will be exchanged (Knack, 2001) with a positive impact on innovative performance. 
In order to single out the distinctive roles of 'bridging' and 'bonding' social capital this paper will build upon existing literature in a number of innovative ways. First, the paper develops an operational definition of social capital (centred on its network dimension) and a clear conceptualisation of the mechanisms linking social capital and innovation by cross-fertilising the literature on the socio-institutional determinants of innovation with the literature on 'bridging' and 'bonding' social capital. Second, while the large majority of the existing analyses on the impact of social capital on regional innovation are based on qualitative methods, this paper adopts a quantitative approach, covering the many different ways in which 'bonding' and 'bridging' can be combined in reality and testing the generality of their impact on innovation. Third, the empirical analysis will also explore the causal nature of these links by explicitly addressing a potential endogeneity bias through a robust identification strategy based on a time lag instrumental variable approach.

The empirical analysis looks at the Italian provinces, an exemplary case study in the literature on social capital (Guiso et al, 2004; Ichino and Maggi, 2000; Putnam, 1993) although - to the best of our knowledge - the link between social capital and innovation has not been explored in depth. Recent studies on social capital in Italy are largely qualitative (Ramella and Trigilia, 2009) while those adopting a quantitative approach focused on selected geographic areas (e.g. industrial districts as in Cainelli et al., 2005) or adopted a firm-based perspective in order to address the impact of social capital on the firms' propensity to innovate and their willingness to invest financial resources in innovative activities (Arrighetti and Lasagni, 2010; Laursen and Masciarelli, 2007) thus failing to develop a more general analysis on the effect of social capital on innovation at 
a meso and macro level. Instead, this paper covers all Italian provinces for an eight-year period and develops two separate measures for bonding and bridging social capital respectively. These measures will be regressed against the innovative activity of Italian provinces and OLS and IV estimates will be presented, fully addressing any endogeneity bias affecting previous studies. The results show that only bridging social capital exerts a positive impact on innovation, whereas bonding social capital is either insignificant or negatively associated with innovation. This result suggests that social capital is a fundamental driver of innovation if and only if it operates as a channel for the exchange of non-redundant and complementary knowledge.

The paper is organized as follows: the second section provides an overview of the literature on the link between innovation and social capital, developing an operational definition of the concept and highlighting the transmission mechanisms in play of, respectively, Bonding and Bridging social capital in respect of innovation. Section three discusses the estimation strategy and the data, while the fourth section presents some key descriptive statistics and the main results discussing their economic implications. Finally some conclusions are drawn underlining the fundamental role of social capital as a determinant of local innovative performance.

\section{How 'bridging' and 'bonding' social capital shapes local innovative performance}

The analysis of the impact of social capital on innovation has suffered from a lack of consensus on its definition, often reflected in a substantial vagueness in its operationalisation and measurement (Guiso et al., 2010). Coleman (1988) argued that it 
coincides with the social structure of a society that facilitated the actions of individuals. Putnam (1993) identified social capital in terms of trust-based relations and groups. Fukuyama (1995) suggested that social capital has to be intended in terms of trust, civicness and network relations. However, these definitions are difficult to operationalise and do not allow us to shed light on the debate on the "dark side" of social capital and overcome the "impasse" on what its optimal endowment would be for purposes of innovation. In addition, from the methodological perspective, several issues are still unresolved. As Solow (1999) pointed out in his critique of Fukuyama (1995), if social capital is to be anything more than a fuzzy concept it must be quantifiable. However, we are still far removed from agreeing upon a universal measure of social capital. Different aspects of social capital have been alternatively emphasized and different measures proposed: from civic cooperation to collective action, from trust to political participation, groups and networking.

The recent evolution of the analysis of the socio-institutional determinants of innovation offers fertile ground for the development of a suitable working definition of 'social capital' and a conceptualisation of its links with innovative performance. A growing body of literature suggests that innovation is a social process embedded in the local social environment that is systematically affected by the strength and intensity of social ties. The emphasis on the social dimension of innovation led to the definition of innovation-prone and innovation-averse regions (Rodriguez Pose, 1999), social filters (Rodríguez-Pose and Crescenzi 2008), innovative milieux (Breschi and Lissoni, 2001; Camagni, 1995), learning regions (Florida, 1995; Morgan, 1997) and regional systems of innovation (Cooke et al, 1997). In all these perspectives, the analysis is focused on 
the network dimension of the innovation process: networks foster innovative capabilities by facilitating the diffusion of valuable and non-redundant knowledge and preventing stagnation and lock-in (Boschma, 2005).

In line with this literature the link between social capital and innovation can be identified in the concepts of networking and embeddedness (Granovetter, 1985). Relational networks connecting individuals, groups, firms, industries with different knowledge bases are a critical precondition for knowledge generation and transfer. In this context innovation emerges from a cumulative process embedded in the social context and systematically affected by processes of interactive learning stimulating the exchange and re-combination of knowledge (Asheim, 1999; Lundvall, 1992).

Social capital is then a crucial pre-condition for innovation since it stimulates interpersonal interactions, the formation of networks and the circulation of valuable knowledge (Tura and Harmakorpi, 2005).

The focus on "relations as central units of analysis" (Boggs and Rantisi, 2003) for innovative performance sheds light on a number of channels through which social capital exerts its influence on innovation. Capello and Faggian (2005) emphasized the role played by relational capital in the generation and diffusion of innovation and in this context knowledge spillovers were deemed transmission channels that are crucial for determining effect of networking and social relations on innovative performance. Kallio et al. (2009) suggested that the link between the social dimension and the emergence of an innovative outcome lies in local absorptive capacity that promoted the diffusion of knowledge within the regional system of innovation. Other authors argued that social capital has only a second order effect and that it is mediated by increasing returns on 
investments in human (Bourdieu, 1986, Gradstein and Justman, 2000, Dakhli and De Clercq, 2004) or physical capital (Becker and Diez, 2004, Fritsch and Franke, 2004, Cainelli et al., 2005).

However, how can these mechanisms explain the 'dark' side of social capital? The potentially detrimental effects of social capital (Akerlof, 1979; Olson, 1982) and its 'optimal' endowment (i.e. the optimal strength and intensity of the relations between individuals) remain unexplained. As Florida (2002) pointed out, places with strong social capital are often the areas with the worst innovative performance. In this context social capital, based on strong relations between individuals, becomes the reason behind the closure of the network and the insulation from external information and challenges.

By looking at social capital as a fundamental component of the socio-institutional environment shaping the process of innovation, this paper contends that differences in the nature of social networks rather than the density of their linkages offer a potential explanation for the non-linear relation between social capital and innovation (Hauser et al., 2007).

The so called "weak ties hypothesis" proposed by Granovetter (1973) is crucial in this context. Relationships between people can be characterized by either frequent contacts and deep emotional involvement or sporadic interactions with low emotional commitment. The former category is generally identified as 'strong ties' - such as the relationships within families or close friends - while the latter is associated with the definition of 'weak ties' linking individuals characterized by loose acquaintances. Contextualising Granovetter's argument into the analysis of innovation, 'weak ties' can be seen at the source of novel information and responsible for the diffusion of ideas 
(Granovetter, 1982; Rogers, 1995), while 'strong ties' increase the risk of exchanging redundant knowledge simply because they connect knowledge seekers with other individuals that are more likely to deal with 'known'/familiar information and knowledge (Levin and Cross, 2004).

In other words weak ties are fundamental in spreading information because they operate as bridge between otherwise disconnected social groups (Ruef, 2002). Weak ties serve as a bridging mechanism between communities within the same society, while strong ties function as a bonding device within homogeneous groups potentially hampering the degree of sociability outside restricted social circles (Beugelsdijk and Smulders, 2003).

'If knowledge stays too much inside [...] bounded communities-when communities mistrust each other - then knowledge will have a limited and uneven spread. Bridging between communities gives the more knowledgeable communities confidence that their knowledge will be used by members of other communities to their mutual benefit.' (Rodríguez-Pose and Storper, 2006, p.8).

Following this line of reasoning it is possible to identify the distinctive influence on innovation exerted by social networks of different kinds: 'connections between heterogeneous groups' whose density and intensity constitute the 'bridging social capital' of a territory vs. 'the links between like-minded people, or the reinforcement of homogeneity' whose density and intensity forms the regional endowment of 'bonding social capital' (Schuller et al., 2000).

Bridging social capital, by lowering transaction costs, contributes to an environment congenial for (high-risk) innovation investment, hence benefitting from ties based on trust and cooperation (Hauser et al., 2007). Conversely, bonding social capital is likely 
to negatively affect innovation because it facilitates small groups lobbying for preferential policies and protection of the status quo, hampering risky innovative activities (Dakhli and De Clercq, 2004; Knack and Keefer, 1997; Portes and Landolt, 1996). In this perspective the 'dark side of social capital' lies in the typology of ties and the radius of trust in the network rather than the overall intensity of the relationships among knowledgeable individuals: we need to look for the 'right' typology, rather than an optimal 'quantity' of social capital if we are to aim at enhancing local innovative performance.

The case of Italy is a particularly appropriate 'laboratory' to test these hypotheses. Putnam (1993) has suggested that one of the main reasons for perpetuation of developmental differences as between the North and South of Italy is to be ascribed to the quality of the institutions and social capital. Arrighetti and Lasagni (2010) analysed the effect of these social conditions on the propensity to innovate of Italian firms and found that innovative firms tend to cluster in those provinces characterized by higher levels of 'positive social capital', construed as civicness and high social interactions, and lower levels of 'negative social capital', generally associated with opportunistic behaviours caused by the coexistence of groups lobbying for specific interests. Following the same line of argument, but focusing on case studies such as the Emilia Romagna industrial districts, Cainelli et al.(2005) argued that extensive horizontal relationships among local economic actors generate positive network externalities favouring the exchange of valuable knowledge and fostering the innovative performance of local firms. 


\section{Model of empirical investigation}

In order to assess the impact of social capital on the innovative performance of Italian provinces, empirical analysis relies on a 'modified' Knowledge Production Function (KPF) approach. The analysis is based on the KPF (formalised by Griliches, 1979; 1986; and Jaffe, 1986) but adopts a place-based perspective, with Italian provinces (NUTS3 level) as units of observation. This specification of the KPF is customary in the literature on regional innovation (Audretsch, 2003; Audretsch and Feldman 1996; Crescenzi and Rodriguez-Pose, 2011; Crescenzi et al., 2007; Feldman, 1994; Fritsch, 2002; Moreno et al. 2005a; O'hUallachain and Leslie, 2007; Ponds et al, 2010; Varga, 1998) and allows us to focus upon the territorial dynamics of innovation by taking account of both total social capital endowment and its bonding and bridging components as determinants of regional innovative performance. The Regional Knowledge Production Function takes the following form:

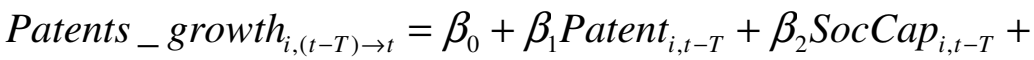

$$
\begin{aligned}
& +\beta_{3} \operatorname{Grad}_{i, t-T}+\beta_{4} \operatorname{privR} \& D_{i, t-T}+\beta_{5} X_{i, t-T}+\delta_{i}+\varepsilon_{i}
\end{aligned}
$$

\section{(Equation 1)}

Where Patents_growth gr,t $-T) \rightarrow t_{T}=\frac{1}{T} \ln \left(\frac{\text { Patents }_{i, t}}{\text { Patents }_{i, t-T}}\right)$ is the logarithmic transformation of the ratio of patent applications in province $i$ at the two extremes of the period of analysis ( $\mathrm{t}-$ $\mathrm{T}, \mathrm{t})$. Among the independent variables $\operatorname{soccap}_{i, t-T}$ is our variable of interest and represents the measure(s) of social capital (Total, Bonding and Bridging) in each

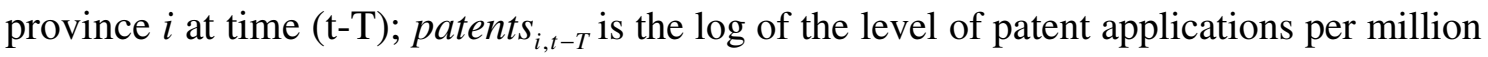
inhabitants at the beginning of the period of analysis (t-T); $\operatorname{privrd}_{i, t-T}$ is private 
expenditure in R\&D as percentage of regional GDP at (t-T); $\operatorname{grad}_{i, t-T}$ is the number of graduates as a percentage of regional population at time $(\mathrm{t}-\mathrm{T}) ; X_{i, t-T}$ is the matrix of additional controls (i.e. regional sectoral composition, population density and female unemployment) at (t-T); Finally, $\delta_{i}$ represents macro-regional dummies for southern, central and northern Italy and $\varepsilon_{\mathrm{i}}$ is the error term. A detailed description of the variables is included in Table A-1 in Appendix A.

Regional Innovative Performance - OECD Patent data are used as a proxy for innovation. The generation of innovation is proxied by the logarithmic approximation of the growth rate of patents over the $2001-2007^{1}$ period. Patent statistics are generally regarded as a reliable measure of innovative output providing comparable information on inventions across different regions and a broad range of technological sectors (OECD, 2001; Sedgley and Elmslie, 2004). Conversely, patent-based innovation indicators fail to account for either the differentiated degree of novelty of patented products (not all patented products are equally 'new' and/or valuable) or the non patentability of many inventions (in particular as regards process innovation). In addition, different sectors appear to have intrinsically different propensities to patent inventions. In order to minimise any potential bias in our analysis: a) there are controls

\footnotetext{
${ }^{1}$ Patent data at the NUTS3 level are in principle available for a longer time series; however data on social capital and other control variables at the provincial level prior to 2001 are unavailable. The empirical analysis is forced to rely on 2001 Census data and some additional specialized data sources for social capital-related variables (Cartocci, 2007) for the computation of the independent variables. In order to capture the dynamic effect of social capital on innovation the dependent variable is computed by covering the time interval between 2001 and the latest available year in the OECD PatStat database (i.e. 2007). Even though still relatively limited, the coverage of an eight year period is a significant improvement on the existent quantitative literature on the link between social capital and innovation in the Italian provinces. All existing studies cover a shorter time span. For example Cainelli et al. (2005) looking at the Emilia Romagna Industrial districts cover the 2002-2007 period; Laursen and Masciarelli (2007), whose analysis is focused on larger geographical units (NUTS2 Regions), still cover a shorter time interval (2001-2003).
} 
for the initial patent intensity of each region, accounting for its initial global propensity to patent; b) there are also controls for the economic sectoral structure. In addition, the specification of the dependent variable in terms of growth rate is an attempt to overcome the lack of panel data and provide some evidence on the dynamic effect of social capital on innovation (Crescenzi et al, 2007): after controlling for the effect of initial conditions in terms of innovative performance (initial level of patenting), social capital and its bonding and bridging components are tested as predictors of a given region's capability to develop based upon existing technological infrastructure and hence improve its innovative performance (patent growth rate).

Initial patent intensity - The initial patent intensity in each province is used as a proxy for the existing technological capabilities and their distance from the technological cutting edge. It also controls for differences in the patenting propensity often related to pre-existent differences in sector specialization as discussed above.

Social Capital - Coherently with the conceptual framework outlined above, the analysis looks at both the total regional endowment of social capital and its constituent components in terms of 'bonding' and 'bridging' social capital. The focus of the empirical analysis is on the networking dimension of social capital, so as to capture its effect on the circulation of knowledge. As previously mentioned this implies a crucial distinction between networks based on weak ties, or bridging social capital, and networks based on strong ties, or bonding social capital.

The analysis relies on data on family characteristics as a proxy for bonding social capital based on strong ties (Beugelsdijk and Smulders 2003; Levin and Cross, 2004; 
Ruef, 2002) and data on voluntary associations as a proxy for bridging social capital based on weak ties operating as forms of horizontal relations fostering networks of civic engagement (Arrighetti and Lasagni, 2010; Beugelsdijk and Schaik, 2005).

As far as bonding social capital is concerned, in order to capture the strength of family ties, the analysis relies on two key indicators: 'the number of families having lunch at least once per week with relatives and close friends (per 100 households)' and 'the number of young adult individuals living with parents (per 100 young adults)'. Strong family ties imply geographical proximity of adult children: young adults tend to stay longer with their parents and relationships within families are particularly strong and based on repeated interactions (Alesina and Giuliano, 2010).

Family characteristics have been at the heart of the existing analyses of social capital in Italy ever since the seminal work by Banfield (1958) who suggested that low propensity to cooperate is generally associated with, among other things, the strength of family ties. In particular, Banfield (1958) pointed out the negative impact on economic development of the low propensity to cooperate which, in its turn, implies high transaction costs. This 'development trap' is the outcome of strong family ties (the socalled 'amoral familism'), high uncertainty and a highly unequal distribution of income and wealth. So far, there has been no conclusive empirical evidence supporting Banfield's hypothesis, but, some recent research provides support to this view. Alesina and Giuliano (2010) find that strong family ties are associated with low levels of generalized trust. Similarly, Giavazzi et al. (2010) relate family types to female labour market participation rate in European regions, whereas Duranton et al. (2009) relate past family structures to a number of contemporary outcomes: they all concur in suggesting 
the existence of a strong link between 'close' family ties and an inward orientation/networking of local societies.

In particular, as far as the 'number of adult individuals living with parents' is concerned, there is consensus in the literature on the importance of cultural factors as an explanation for their delayed transition into adulthood. Reher (1998) distinguishes the 'weak family ties' tradition of Northern Europe whereby children leave parents' home relatively early in their life from the 'strong family ties tradition' in Southern Europe whereby children move away from their parents at a later stage. Manacorda and Moretti (2006) and Giuliano (2007) provide additional empirical evidence on the role of cultural factors in explaining co-residence of parents and children.

Despite the broad consensus on the relevance of family ties as a proxy for bonding social capital it is still possible that - in practice - the variables included in our composite indicator could be correlated with characteristics of the local society other than social capital. In particular the proxy 'number of adult individuals living with parents' could be associated with the differential availability of employment opportunities for young individuals in different provinces rather than with actual differences in cultural background. In order to rule out this possibility the composite indicator for bonding social capital is preliminarily regressed on 'youth unemployment rate' while controlling for additional covariates that will be also included in the final specification $^{2}$ of the model. The results show that the composite indicator of bonding social capital is not significantly correlated with youth unemployment, ruling out any spurious correlation and supporting its inclusion into the KPF as a genuine proxy for boding social capital.

\footnotetext{
${ }^{2}$ Population density, spatial lag of population density, female unemployment, employment in agriculture and services and macro regional dummies. Results for these robustness checks are not presented in the 14 paper but they are available on request.
} 
Bridging social capital based on weak ties is, instead, measured by means of two 'traditional' indicators widely used in the economic literature. 'Blood donations' (Blood donations per 1000 residents) and 'participation in voluntary associations' (number of voluntary associations per sq.km) proxy the participation of individuals in activities with positive social externalities and are a measure for their altruism (Cartocci, 2007). Both selected indicators are customary in the economic literature on bridging social capital. For example, in line with Putnam (1993), Guiso et al. (2004) use both variables to proxy social capital in Italian provinces as measures of pro-social behaviour. A similar approach is adopted by Nannicini et al. (2010).

The capability of these variables to proxy bridging social capital is also reinforced by some specificities of the Italian case. First of all, it should be borne in mind that blood donations are completely free in Italy and national regulations do not allow for any form of monetary compensation for donors. In addition AVIS (Italian National Association of Blood Donors) data confirm that blood donations clinics are equally accessible and evenly distributed across provinces and regions in the entire country ${ }^{3}$.

Second, empirical evidence also makes it possible to rule out the possibility that the density of voluntary associations could be considered also as a proxy for urbanization economies: when the composite indicator for bridging social capital is regressed on the 'number of firms per Kmq' there is no evidence of any significant correlation ${ }^{4}$.

\footnotetext{
${ }^{3}$ Blood donations clinics are generally present in each municipality with a stardard deviation in the density of blood donations clinics per Kmq of just 0.010 . The table with descriptive statistics on the geography of blood donation clinics in Italy is not included in the paper but is available from the authors upon request.

${ }^{4}$ This regression includes controls for additional covariates such as population density, spatial lag of population density, female unemployment, employment in agriculture and services and macro regional dummies. All these regressors will also be included in the main specification of the KPF. Table with the 15 results of this additional robustness check is available upon request.
} 
The two proxies for bonding social capital discussed above ('number of families having lunch at least once per week with relatives' ${ }^{5}$ and the "number of young adults living with parents ${ }^{6}$ ) are combined into a composite indicator of bonding social capital while the 'number of blood donations' and 'number of voluntary associations' are combined in a composite indicator for bridging social capital. An additional measure of 'total' social capital encompassing both its bonding and bridging dimension is also computed in order to detect the overall effect of social capital on innovation.

Our social capital composite indicators are computed in line with the indicators of technological capabilities (ArCo) by Archibugi and Coco (2005). The 'Total Social Capital' indicator combines both 'bonding' and 'bridging' social capital variables with equal weights:

$$
\text { Socialcapital }=\sum_{i=1}^{2} \lambda_{i} I_{i}
$$

Where $\mathrm{I}_{\mathrm{i}}$ represents each of the two components of social capital (bonding and bridging) and $\lambda_{\mathrm{i}}$ is the constant equal to $1 / 2$. The indexes $I_{i}$ for each component (bonding and bridging) are, in their turn, calculated with the same procedure using the simple mean of the corresponding social capital variables normalised to vary from 0 to 1 as follows:

$$
I_{i}=\frac{\text { Observed_value }- \text { Minimum_observed_value }}{\text { Maximum_observed_value }- \text { Minimum_observed_value }}
$$

Social capital variables cover all Italian Provinces (NUTS3 level) ${ }^{7}$ and are available from ISTAT (Italian National Statistical Office) ${ }^{8}$. The use of composite indicators as proxies for social capital endowment is customary in the literature and reflects the multifaceted nature of this concept. In addition, the use of composite indicators is

\footnotetext{
${ }^{5}$ Per 100 households

${ }^{6}$ Per 100 young adults

${ }^{7} 103$ observations

${ }^{8}$ See Table A1 for further detail.
} 
crucial for the identification strategy discussed below: given the significant constraints in terms of historical data availability at the sub-national level it would be impossible to identify suitable instruments for each social capital variable separately.

Innovation input- 'Private $\mathrm{R} \& \mathrm{D}$ as a share of GDP' and the number of graduates over the total population are used as proxies for the key inputs of the 'standard' regional Knowledge Production Function (Crescenzi et al., 2007; Moreno et al., 2005b; O’hUallachain and Leslie, 2007; Ponds et al., 2010; Varga, 1998). On account of limited data availability our R\&D measure is available only at regional level (NUTS 2) while the number of graduates is available for each province (NUTS3).

Controls - Our specification of the knowledge production function includes controls for population density at the provincial level, labour market characteristics in terms of female unemployment rate, and sector structure measured by the share of employment in agriculture and services ${ }^{9}$.

The sectoral composition is controlled for by using data on employment for three sectors: agriculture, industry and services and is interpreted as a measure of specialization. All controls are available at the provincial level (NUTS3) from ISTAT. The analysis includes additional controls to minimise the impact of spatial autocorrelation in the error term. In particular, it includes the spatial lag of population density as a measure of accessibility and macro-regional dummies (north, south and

\footnotetext{
${ }^{9}$ Additional controls on sector structure (such as the Herfindal Index) were also included in the model with no statistically significant effect. In order to keep our specification as simple as possible (parsimony) these variables were excluded from the final specification of the model presented in the paper but additional regression tables are available on request.
} 
centre) in order to control for time-invariant area characteristics and other unobserved sources of spatial autocorrelation (Armstrong, 1995; Rodriguez-Pose, 1999).

Identification strategy - The next question is how to identify the link between innovation and social capital given the potential endogeneity of social capital on account of both reverse causality and omitted variable bias.

The key research hypothesis in this paper is that social capital can be treated as a determinant of innovation as it leads to the development of networks between knowledgeable individuals, thereby stimulating the circulation and diffusion of knowledge and favouring the re-combination of valuable information. In addition, the effect of social capital on innovation is supposed to depend on the extension of such networks' radius of trust: weak ties, bridging members of different epistemological communities, are more efficient than strong ties within the same group as a stimulus for innovation.

Even if grounded in a large body of literature and supported by robust qualitative evidence, this argument may overlook the possibility that causality runs in the opposite direction: more innovative provinces might be able to generate - through economic incentives sufficiently high as to create valuable networks - a virtuous cycle based on cooperation and trust, stimulating civicness and a sense of community. In addition, an omitted-variable problem may also bias the estimation of the model. The measures of social capital are potentially correlated to local characteristics that cannot be fully controlled for. This is particularly problematic when considering neighbouring effects and spatial correlation: the omitted variable bias may depend on both local characteristics and neighbouring areas features affecting local innovative performance. 
Finally the adoption of proxies and the construction of composite indicators of total, bridging and bonding social capital may potentially exacerbate the measurements errors in our variable of interest.

In order to minimize the impact of all these problems, the model controls for spatial correlation by including the spatial lag of social capital and a set of macro-regional dummies. Furthermore, the potential endogeneity of social capital is dealt with by adopting an instrumental variable approach (2SLS). In particular, levels of bonding and bridging social capital in each province are instrumented with the 'number of mutual organizations in 1911' and the 'average political participation in referendums ${ }^{10}$, respectively. For both instruments the analysis relies on regional-level ${ }^{11}$ data due to the lack of historical quantitative information at the provincial level.

In order to understand the rationale behind our identification strategy it is important to consider that in the case of social capital the selection of an appropriate instrument is constrained by two major factors. First, as discussed above there is still no consensus on a single definition of social capital and its measure (Guiso et al., 2010). This implies that the search for an appropriate instrument cannot build on the micro-foundations of the concept. Second, there are major problems in recovering reliable time series for the key social capital proxies, especially when the analysis is performed for sub-national geographical units. This explains why - we were unable to use a panel structure for our analysis and why we are not able to use the standard Instrumental Variables time lag approach based on the lagged values of the variables of interest (Putnam, 1993).

\footnotetext{
${ }^{10}$ The measure is constructed as the average political participation in the following referendums: 1946 (Monarchy vs. Republic), 1974 (divorce), 1978 and 1981 (abortion), 1985 ("scala mobile") and 1987 (nuclear power). The average measure is used in order to limit the potential bias coming from peculiar ideological positions in different regions with respect to particular questions.

${ }^{11}$ Available in Nuzzo (2006), see Table A-1 for further detail.
} 
In order to overcome both shortfalls the existent empirical literature on the economics of institutions and culture in general and on social capital in particular has made extensive use of alternative historical proxies as instruments.

The existing literature on the impact of social capital, by building on both the theoretical framework of the overlapping-generations model and the multidimensionality of social capital (Guiso, Sapienza, Zingales, 2008), has suggested that inter-generationally transmitted priors and social structures (measurable by means of different but correlated variables) affect individual decisions regarding whether to trust other members of the society or just the member of a restricted group (Tabellini 2010). As a consequence, in line with the existing literature, the identification strategy is not based on a causal link between 'mutual organizations in 1911', 'referenda turnout' and the 'bonding' and 'bridging' social capital indicators. On the contrary, the proposed instrumental variables - in absence of reliable historical data on the social capital indicators at the beginning of the $20^{\text {th }}$ century - are considered as alternative proxies for past stocks of bonding and bridging social capital and adopted as time lag instruments (Tabellini, 2010, Putnam, 1993, Tomassini, 1999).

Our instruments - 'number of mutual organizations in 1911' and 'voter turnout in selected referendums' - are then both designed to proxy past social capital stock. In particular, the first instrument is expected to be postiviely correlated with bonding social capital while 'turnout in referendums' is assumed to be positively correlated with bridging social capital as it is considered in the literature as a proxy for civic participation and engagement. 
As far as the instrument for bonding social capital is concerned, it should be borne in mind that the aim of Italian 'mutual organisations' was to assist exclusively their own members: they contributed to enhance cooperation only within a restricted and exclusive group of people belonging to the same professional, political or social environment. These organisations were funded by their members with the aim to provide common services to their own members. Their activities were based on the principle of mutuality (or strict reciprocity) whereby non-members are excluded from any benefit. The very first mutualistic organizations were established in Northern Italy soon after 1848 but their number grew substantially after the Unification of the country as a 'private' response to the absence of a public welfare system (Tomassini, 1999). In other words, mutuals were established as a private supply of impure public goods (such as health care) to the benefit of their members, whereas non-members were excluded. This characteristic is crucial for our analysis. The density of mutual organizations at the beginning of the 20th Century can be interpreted as a predictor for strong group ties within groups of like-minded individuals: a form of 'bonding' that fosters cooperation only among the members of a well-identified homogenous group. As a consequence, this variable is meant to measure a long temporal lag in our bonding social capital indicator.

Conversely, the historical turnout in referendums of 'general' relevance can be interpreted - in line with a large body of literature - as a proxy for the propensity of people to participate in social life and to bridge with other groups: a long lag of our bridging social capital indicator. This choice is also supported by Putnam's (1993) view of participation in 'general interest' referendums as radically different from turnout in political elections. While all parties involved in political elections are largely motivated 
by self-interest (being elected for candidates, having their instances represented in the relevant institutional bodies for their electors), participants (promoters, campaigners and voters) in referendums are directly interested in promoting change at the level of the entire society and their self-interest (if any) remains very limited (Putnam 1993).

\section{Empirical results}

Table 1 presents some descriptive statistics on the link between the innovative performance of Italian provinces and the characteristics of their social capital environment: the growth in patents, the composite measure of social capital and its two sub-components (bonding and bridging). As the variation in the mean value of the composite measure of total social capital as between different macro-areas (North, Centre, South) is not particularly relevant it can cast doubts on the explanatory power of total social capital for differential innovative performance.

However, a more accurate understanding of this preliminary evidence is provided by the mean value of the proxies for bonding and bridging social capital. Table 1 shows that the macro-area with the best innovative performance (North) is characterized by the highest level of bridging social capital and the lowest level of bonding social capital. Conversely, southern regions show the opposite pattern. Furthermore, the heterogeneity in terms of bonding and bridging social capital as between different macro-areas is particularly significant: bonding social capital is significantly higher in southern regions while the highest levels of bridging social capital seems to be concentrated in the North. 
The preliminary analysis of these indicators offers some interesting insights. Thus rather than the total amount of social capital (measured as the combination of bonding plus bridging social capital) the size of the bonding and bridging components is found to correlate with the innovative performance of the different macro-areas. Bonding social capital is negatively correlated to innovation while bridging social capital shows a positive correlation with innovative performance.

This preliminary evidence seems to support the main hypothesis of our analysis: social capital seems to have a beneficial effect on local innovative performance when it is based on weak ties between otherwise disconnected communities. Conversely, a predominance of bonding social capital is associated with weaker innovative performance. The double-sided effect of social capital on innovation is further confirmed by the correlation matrix in Table 2 . Bridging social capital is positively associated with higher innovative performance while the correlation with bonding social capital is negative. Moreover, the correlation between the two dimensions of social capital is highly negative indicating the strong divide between high bonding and high bridging areas that characterises Italy's geography of social capital .

Figure 1 shows the distribution of the composite measure of total social capital at the provincial level. Areas with a high level of social capital are fairly equally distributed over the whole country with peaks in both southern and northern regions, confirming the provincial level (NUTS3) as the relevant spatial unit for the analysis of social capital. Figures 2 and 3 show the distribution of bridging and bonding social capital respectively. Bridging social capital seems to be systematically higher in Northern Italy and in part of the Central regions while Southern provinces are characterized by a strong 
predominance of bonding social capital. This is the result of the different historical trajectories of these areas: areas where independent city-states (the so-called Repubbliche Comunali) used to exist now benefit from higher levels of trust and government effectiveness, lower reliance on 'family' networks and higher 'bridging' social capital (Guiso et al. 2008, Percoco 2010a and 2010b have provided empirical support for this idea).

In line with the descriptive statistics, the spatial distribution of innovation (Figure 4) ${ }^{12}$ does not show any obvious association with the geography of total social capital. Areas characterized by a stronger innovative performance - such as provinces in Veneto, Trentino Alto Adige, Friuli Venezia Giulia and part of Piedmont - show a lower level of social capital while traditionally low-innovation areas (such as those in Sicily and Apulia) are characterized by a relatively stronger total social capital endowment. Conversely, the percentile map of bridging social capital shows a much better spatial matching with the distribution of innovation, supporting the crucial role of weak ties as a precondition for innovation at the provincial level.

Table 3 reports the estimation results for the Regional Knowledge Production Function specified in Equation 1. In the basic specification only the 'traditional' inputs of the KPF (R\&D Expenditure and Human Capital) are included in the model together with the initial level of patenting in each province (Tab.3, Col.1). The initial number of patents per million inhabitants is statistically significant at $1 \%$ level and negatively associated with the dependent variable. This suggests a (weak) convergence in

\footnotetext{
${ }^{12}$ The percentile map of innovation is based on the level of patenting in 2001 in order to provide a static picture of the spatial pattern of the variables of interest at the same point in time.
} 
innovative performance in line with existing regional-level research on Europe and the United States (Crescenzi and Rodriguez-Pose, 2011; Crescenzi et al 2007; Moreno et al. 2005b), and reflects a weak trend in (conditional) technological convergence in advanced economies. In the Italian case this trend reflects the crisis of traditionally successful innovative areas (such as the industrial districts) and the emergence of some new successful players. The 'core' long-established areas of the "Made in Italy" - such as the industrial districts specialized in the production of leather goods and shoes mainly in Tuscany and Marches- experienced a negative dynamic in productivity, while other areas - in particular those specialised in chemistry and oil (spatially concentrated in Tuscany and Sicily) and metallurgy (Tuscany and Sardinia) or the industrial districts specialized in clothing (Veneto and Apulia) and eyewear (Veneto, Emilia-Romagna and Friuli-Venezia Giulia) - showed an economic performance significantly above the national average (ISTAT Annual Report, 2007/2008).

Regional Investment in $R \& D$ is highly significant and positively associated with innovative performance but in this specification of the model there is no evidence of any impact of human capital endowment on innovation. Investments in $R \& D$ are generally weak in Italy (1.2\% of GDP in 2010, the lowest rate in the EU-15) in sharp contrast with the above EU-average intensity of the leading provinces in Lombardy and EmiliaRomagna generating a highly localised geography of innovative efforts.

Subsequently, controls for population density, labour market characteristics, sector structure, the spatial lag of population density (as a proxy for accessibility) were introduced into the model (Table 3, column 2). Neither the level of female unemployment (proxy for the efficiency of the local labour market), nor the measures of sector specialisation (the share of employment in agriculture and services) are 
statistically significant. The highly regulated Italian labour market does not exert any influence on local-level innovative performance. The same is true for regional specialisation patterns, which are heavily constrained by low factor mobility and lack of critical mass in average firm-size. What matters for innovation - and this result remains robust in subsequent specifications of the model - are agglomeration economies: population density is positively associated with innovation with a $10 \%$ significance level while the spatial lag of population density shows a statistically significant negative effect on innovative performance. The most innovative provinces are those where density is higher (major urban areas with their functional hinterland) and surrounded by less dense provinces from which they absorb labour force commuting across their functional borders. Once the underlying geography of Italian innovation is fully controlled for (by means of the proxies discussed above) the impact of regional human capital endowment becomes positive and statistically significant at $10 \%$ level. This would put Italy in line with other EU countries and the US where local human capital is a key driver of innovative performance (Crescenzi et al. 2007). However, as will be discussed below, the impact of regional human capital is not sufficiently robust to allow for the inclusion in the model of controls for the North-South divide, clearly reflecting the fundamental mismatch between (Southern) graduates' skill profile and their occupations (Iammarino and Marinelli, 2011).

In column 3, total social capital is introduced into the model showing a positive and significant (5\% significance level) impact on innovation. In column 4 neighbourhood effects and spatial autocorrelation are controlled for by introducing the spatially lagged 
value of total social capital endowment together with the macro-regional dummies ${ }^{13}$. The measure of social capital remains positively associated with innovation with a significance level of $5 \%$. After fully controlling for the North-South divide and other spatial effects social capital emerges as the most important predictor of innovative performance together with our proxy for agglomeration economies. Highly agglomerated provinces - where face-to-face contacts maximise the exchange of knowledge - with high levels of cooperation and associational activities (high total social capital) show the best innovative performance. This result provides quantitative confirmation for the qualitative evidence of some existing studies on innovation and social capital (Biagiotti, 2008; Ramella and Trigilia, 2009; Ramella and Trigilia, 2010). Furthermore, the empirical strategy adopted in this paper makes it possible to test the differential impact of different 'qualities' of social capital and isolate the effect of the two fundamental components of social capital: bonding social capital based on strong ties, and bridging social capital, based on weak ties. For this purpose the measure of total social capital is split into two separate indicators (Table 3, column 5) one for bonding and the other for bridging social capital. The regression results show that the bridging component is statistically significant at the $1 \%$ level and positively associated with innovation while bonding social capital is not significant and negatively associated with innovative performance. Bridging social capital alone remains the single most important predictor of innovative performance. This evidence suggests that the positive and significant effect of social capital on innovation is largely based on weak ties rather

\footnotetext{
${ }^{13}$ The Moran's I over the residuals is calculated in order to test for spatial correlation. After controlling for the spatial lag of population density and social capital and adding macro'regional dummies the coefficient of the Moran's I becomes statistically insignificant. The p-value further confirms the rejection of the null hypothesis of spatial autocorrelation in the residuals. The spatial autocorrelation tests on the residuals are available on request and confirm the robustness of our results (Gibbons and Overman 2010).
} 
than strong ties. Weak ties allow access to non-redundant information, favouring the transfer and re-combination of valuable knowledge.

The robustness of these results is tested against a potential endogeneity bias by means of an instrumental variable (IV) approach: 2SLS results are shown in Table 3, Column 6. The IV results strongly support the existence of a causal link between bridging social capital and innovation (positive coefficient and statistically significant at $1 \%$ level), while bonding social capital remains statistically insignificant and negatively associated with innovation. Once the potential endogeneity of social capital is fully accounted for the significance of bridging social capital increases substantially, making it the most important predictor of innovative performance. First stage regressions (shown in Table 4) confirm the validity of this instrumental strategy. Both instruments - mutual organizations in 1911 and referendum turnout - are highly correlated to the instrumented variables - bonding and bridging social capital respectively - showing the expected signs and confirming the rational for their selection.

In addition, the econometric literature on instrument validity suggests that it is possible to encounter the problem of weak instruments even with an unproblematic first stage regression (Staiger and Stock, 1997; Stock and Yogo, 2005). In order to rule out the risk of weak instruments we refer to both the rule of thumb applied by Greiger and Stock (1997) and to the Stock and Yogo's (2005) threshold values. The F statistics in the first stage are above the critical value and close to the value of 10 for the bridging and bonding instruments respectively and are generally above the threshold values reported 
by Stock and Yogo $(2005)^{14}$ (as shown in Table 5). Consequently, our instrumental variables strategy is robust and unaffected by any potential weak instrument bias.

\section{Further robustness checks}

To confirm the robustness of the statistical findings discussed above, a number of additional robustness checks were implemented. In Table 6 the key specifications of the model of empirical analysis were re-estimated with the dependent variable in levels (rather than in growth rates). When compared to the initial specification, where patent growth-rate was used as dependent variable while also controlling for the initial patent intensity in each province, this additional specification aims to capture the dynamic effect of social capital on innovation in a complementary manner. The measure of social capital is regressed against the innovative performance of Italian provinces in subsequent years in order to test for a path-dependency associated to the social capital dimension.

Columns 1, 2 and 3 in Table 6 report the estimation results using, respectively, the number of patents per million of inhabitants in 2002, 2005 and 2007 as dependent variables $^{15}$, while controlling for the potential endogeneity of social capital by means of the instrumental-variables approach. These additional results confirm the robustness of the relation between bridging social capital and innovation and show that it is stronger over time, highlighting a path-dependency/cumulative effect of social capital on innovation. In addition, it is important to notice that bonding social capital is now not

\footnotetext{
${ }^{14}$ The F statistic is above all the Stock and Yogo (2005) threshold values for the instrument for bridging social capital and above the $15 \%$ critical value for the instrument adopted for bonding social capital.

${ }^{15}$ Note that the number of observation is changing in 2002 because the dependent variable is available for 97 provinces out of 103 only.
} 
only strongly negative but also statistically significant (in 2002), further reinforcing the contrast between the two components of social capital.

As a final robustness check, the instrumental variable regressions were re-estimated by progressively eliminating all control variables (Table 7). This showed that the effect of bridging and bonding social capital remains consistent in all specifications of the model independently of their inclusion of additional regressors. This suggests that social capital has an independent effect on innovation above and beyond its potential second order effect on physical and human capital.

Finally, in order to provide further support to the instrumental variable approach the reduced form equation is re-estimated by means of an ordinary least square regression of the dependent variable of interest on the instruments and exogenous variables. As shown by Angrist and Krueger (2001) the effects estimated in the reduced form tend to be proportional to the coefficients of interest. As a consequence the reduced form can be used to determine the sign of these coefficients. In addition, where the reduced form estimates do not differ significantly from zero (as in the case of our instrument for bonding social capital), it is possible to rule out the risk of weaknesses of the instruments ${ }^{16}$ and the reduced form can be used as an additional test for the absence of the effect of interest (Angrist and Krueger, 2001). The estimation of the reduced form equation is reported in Table 8 (Col. 2): the results confirm that bridging social capital is a positive and relevant determinant of innovation while bonding social capital tends to be both negatively correlated to innovation and not statistically significant.

\footnotetext{
${ }^{16}$ As confirmed by the results of the first stage as well as by the test on first stage F stat
} 


\section{Conclusions}

A large body of literature has looked at the very different ways in which social capital influences economic and social activities. However, the analysis of its impact on innovation has remained relatively underexplored. While some contributions emphasized a positive effect others warned against the 'dark side' of social capital when discussing innovation. The analysis of innovation has suffered from the lack of a suitable working definition of social capital as also from the difficulties in operationalising links to innovation dynamics. This paper contributes toward overcoming this deficiency by treating social capital as a networking and associational activity between knowledgeable individuals and a fundamental determinant of innovation by virtue of its being a mechanism for the diffusion and circulation of valuable knowledge. In this perspective, the effect of social capital on innovation is shaped by its capability to facilitate the exchange of complementary knowledge between individuals belonging to different epistemic communities (bridging social capital) - rather than within homogeneous like-minded groups (bonding social capital) making it possible to access non redundant information and preventing cognitive lockin. This paper has empirically tested these hypotheses by means of a quantitative analysis of the innovative performance of the Italian provinces. Notwithstanding the significant data limitations affecting all quantitative research on social capital and its effect, the results are clear-cut and robust.

Social capital is an important predictor of innovative performance after controlling for the 'traditional' knowledge inputs (R\&D investments and human capital endowment) and for other characteristics of the local economy. However, 'bridging' social capital based on weak ties - can be isolated as the key driver of the process of innovation while 
'bonding' social capital is generally negative for innovation. This evidence suggests that - when dealing with innovation - it is crucially important to look at the nature of the networks generated and supported by social capital. It is the radius of trust of network relations that matters rather than their density or intensity. The empirical analysis has devoted special attention to the potential endogeneity of social capital that might bias the estimation of its impact on innovation. The instrumental variable approach has made it possible to identify a clear causal link between bridging (positive) and bonding (negative) social capital and innovation. The identification of these links suggests that the networking dimension of social capital can be considered a viable innovation policy target. Changes in the local endowment of social capital are certainly hard to promote through public policies, but carefully designed innovation policies can contribute towards making changes in the local balance as between bonding and bridging social capital. Policies based on the mobility of 'knowledgeable individuals' and cooperative research projects can contribute to reinforcing the external projection of existing networks among innovative agents. In addition, policies targeting the university system (largely public and heavily 'localistic' in Italy) in order to design recruiting mechanisms for research students and staff more open to 'outsiders' would also facilitate the development of 'bridging' social capital. Further exploration of these policy options remains in our agenda for future research but this paper is a step towards opening the way to a more systematic quantitative exploration of the link between innovation and social capital as an important pre-condition for policy analysis. 


\section{References}

Akcomak, S. and Ter Weel, B., (2009), "Social capital, innovation and growth: evidence from Europe", European Economic Review, 53 (5): 544-67.

Akerlof, G. A., (1979), "The Case Against Conservative Macroeconomics: An Inaugural Lecture," Economica, XLVI: 219-37.

Alesina, A., and Giuliano, P., (2010), "The Power of the Family.",Journal of the European Economic Association, forthcoming.

Angrist, J.D., and Krueger, A. B., (2001), "Instrumental Variables and the Search for Identification: From Supply and Demand to Natural Experiment", Journal of Economic Perspectives, 15(4): 69-85

Archibugi, D., and Coco, A., (2005), "A New Indicator of Technological Capabilities for Developed and Developing Countries (ArCo)", World Development, 32 (4): 629654.

Armstrong, H. W., (1995) "An Appraisal of the Evidence from Cross-Sectional Analysis of the Regional Growth Process within the European Union”, in: Vickerman, R. W., Armstrong, H. W. (Eds.), Convergence and Divergence Among European Regions, Pion Limited, London.

Arrighetti, A. and Lasagni, A., (2010), "Capitale Sociale, Contesto Istituzionale e Performance Innovative delle Imprese”, Scienze Regionali, 10: 5-34.

Asheim, B., (1999), "Interactive learning and localised knowledge in globalising learning economies”, GeoJournal 49: 345-52.

Audretsch, D. B., (2003), "Innovation and spatial externalities", International Regional Science Review, 26: 167-174.

Audretsch, D.B. and Feldman, M.P., (1996), "R\&D spillovers and the geography of innovation and production", American Economic Review, 86: 253-273.

Audretsch, D.B. and Feldman M.P., (2004),'Knowledge spillovers and the geography of innovation", in: J.V. Henderson and J.-F. Thisse, Editors, Handbook of Regional and Urban Economics vol. 4, Elsevier, Princeton, NJ, pp. 2713-2739.

Banfield, E. C., (1958), The moral basis of a backward society, Chicago: Free Press.

Becker, W. and Diez J., (2004), "R\&D Cooperation and innovation Activities of firms. Evidence for the German Manufacturing Industry", Research Policy, 33: 209-223

Beugelsdijk, S., and Smulders, S., (2003), "Bridging and bonding social capital: Which type is good for economic growth?", Paper presented at the European Regional Science Association, Jyvaskila, Finland. 
Beugelsdijk, S. and van Schaiik T., (2005)," Social capital and growth in European regions: an Empirical test", European Journal of Political Economy, 21: 301-324

Biagiotti, A., (2008), "I sistemi locali leader nei brevetti", in: C. Trigilia, Ramella, F. , Imprese e territori dell'alta tecnologia in Italia, Prato: Iris.

Boggs, J. S. and Rantisi, N. M., (2003) "The 'relational turn' in economic geography", Journal of Economic Geography, 3: 109-116.

Boschma, R. A., (2005), "Proximity and Innovation: A Critical Assessment", Regional Studies, 39(1): 61-74.

Bourdieu, D., (1986), "The Forms of Capital” in Richardson, J. Handbook of theory and Research for the Sociology of Education, Greenwood, New York: 241-258.

Breschi, S., Lissoni, F., (2001), “ Localised knowledge spillovers vs. innovative milieux: knowledge "tacitness" reconsidered", Papers in Regional Science 90: 255-273.

Cainelli, G., Mancinelli, S. and Mazzanti, M. (2005), "Social capital, R\&D and industrial District", Feem Working papers n. 744584.

Camagni, R.P., (1995), "The concept of "innovative milieu" and its relevance for public policies in European lagging regions", Papers in Regional Science 74: 317-340.

Capello, R. and Faggian, A. (2005) "Collective Learning and relational capital in Local Innovation Processes" Regional Studies 39: 75-87.

Cartocci, R., (2007), Mappe del tesoro: atlante del capitale sociale in Italia, Bologna: Il Mulino .

Cohen, S. and Fields, G., (2000), "Social Capital and Capital Gains: An Examination of Social Capital in Silicon Valley" in: Understanding Silicon Valley, edited by Martin Kenney, pp. 190-217. Stanford: Stanford University Press.

Coleman, J.S., (1988), "Social Capital in the Creation of Human Capital," American Journal of Sociology, 94: S95-S120.

Cooke, P., Uranga, M.G. and Etxebarria G., (1997), "Regional innovation systems: institutional and organisational dimensions", Research Policy 26: 475-491.

Crescenzi, R. and Rodríguez-Pose A. (2011) Innovation and regional growth in the European Union. Springer, Berlin, Germany.

Crescenzi, R., Rodríguez-Pose, A. and Storper, M., (2007), "The territorial dynamics of innovation: a Europe-United States comparative analysis", Journal of Economic Geography, 7: 673-709. 
Dakhli, M. and De Clercq, D. (2004) "Human Capital, Social Capital and Innovation: A Multi-country Study", Entrepreneurship and Regional Development 16(2): 107-28.

Di Pasquale, D. and Glaeser, E., (1999), "Incentives and social capital: are homeowners better citizens?", Journal of Urban Economics, 45 (2): 354-384.

Duranton, G., Rodríguez-Pose, A. and Sandall, R., (2009), "Family Types and the Persistence of Regional Disparities in Europe", Economic Geography 85(1): 23-47.

Feldman, M.P., (1994), The Geography of Innovation, Boston: Kluwer Academic Publishers.

Florida, R., (1995), “Towards the learning region”, Futures, 27(5): 527-536.

Florida, R., (2002), The rise of the creative class: and how it's transforming work, leisure, community, and everyday life, New York, Basic Books,.

Fritsch, M., (2002), "Measuring the quality of regional innovation systems: a knowledge production function approach", International Regional Science Review, 25: 86-101.

Fritsch, M. and Franke, G., (2004), "Innovation, Regional Knowledge Spillovers and R\&D Cooperation" Research Policy, 33: 245-255.

Fukuyama, F., (1995), Trust: The Social Virtues and the Creation of Prosperity, New York: Free Press.

Giavazzi F., Schiantarelli F., Serafinelli, M., (2010), "Attitudes, Policies and Work". Working Paper.

Gibbons S, Overman H., (2010), "Mostly Pointless Spatial Econometrics". SERC Discussion Paper 61.

Giuliano, P. (2007), "Living Arrangements in Western Europe: Does Cultural Origin Matter?", Journal of the European Economic Association, September 5(5):927-952.

Goldin, C. and Katz, L., (1999), "Human capital and social capital: the rise of secondary schooling in America, 1910-1940", Journal of Interdisciplinary History, 29: 683-723.

Gradstein, M. and Justman, M., (2000), "Human Capital, Social capital and Public Schooling” European Economic Review, 44: 879-891

Granovetter, M. S., (1973), “The strength of weak ties”. American Journal of Sociology 78: $1360-1380$.

Granovetter, M. , (1982), "The strength of weak ties: A network theory revisited", in Marsden \& N. Lin (Eds.): Social structure and network analysis, Beverly Hills, CA: Sage. 
Granovetter, M., (1985), "Economic Action and Social Structure: The Problem of Embeddedness," American Journal of Sociology, 91(2): 481-510.

Griliches, Z., (1979) "Issues in Assessing the Contribution of Research and Development to Productivity Growth." Bell Journal of Economics, 10 : 92-116.

Griliches, Z., (1986), "Productivity, R \& D, and the Basic Research at the Firm Level in the 1970's", American Economic Review 76: 141-54.

Guiso, L., Sapienza P., Zingales L., (2004), "The Role of Social Capital in Financial Development", American Economic Review, 94 (3): 526-556.

Guiso, L, Sapienza P. and Zingales L., (2008) "Long Term Persistence", NBER Working Paper 14278

Guiso, L., Sapienza P. and Zingales L., (2010), "Civil capital as the missing link" NBER Working Paper 15845.

Hauser, C., Tappeiner, G. and Walde, J., (2007), "The Leaning Region: The Impact of Social Capital and weak Ties on Innovation”, Regional Studies 41 (1): 75-88.

Iammarino S. and Marinelli E., (2011), "Is the grass greener on the other side of the fence? Graduate regional mobility and job satisfaction in Italy", Environment and Planning A, forthcoming.

Ichino, A. and Maggi, G., (2000), "Work Environment and Individual Background: Explaining Regional Shirking Differentials in a Large Italian Firm.” Quarterly Journal of Economics, 115: 1057-1090.

ISTAT (2007), “Rapporto Annuale : la situazione del Paese”, Rome: Istat

ISTAT (2008), “Rapporto Annuale: la situazione del Paese”, Rome: Istat

Jaffe, A., (1986), "Technological Opportunity and Spillovers of R\&D: Evidence from Firms' Patents, Profits and Market Value," American Economic Review, LXXVI: 9841001.

Kallio, A., Harmaakoorpi, V. and Pihkala, T. (2009), "Absorptive Capacity and social Capital in Regional innovation System: the Case of the Lahti Region in Finland", Urban Studies 47: 303.

Knack, S., (2001), "Trust, associational life and economic performance". in ed. J. F. Helliwell, The contribution of human and social capital to sustained economic growth and well-being . Ottawa: HDRC.

Knack, S. and Keefer, P., (1997), "Does Social Capital Have an Economic Payoff? A Cross-Country Investigation”, Quarterly Journal of Economics, 112 (4): 1252-88. 
La Porta, R., Lopez de Silanes, F., Shleifer A. and Vishny R.W., (1997), “Trust in Large Organizations", American Economic Review, 87 (2): 333-338.

Laursen, K. and Masciarelli, F., (2007), "The Effect of regional Social Capital and External Knowledge Acquisition on Process and Product Innovation" DRUID Working Paper

Levin, D., and Cross, R., (2004), "The strength of weak ties you can trust: The mediating role of trust in effective knowledge transfer", Management Science, 50: $1477-1490$.

Lundvall B., (1992) "Introduction", in B.- $\AA$ Lundvall (ed.) National systems of innovation. Towards a theory of innovation and interactive learning, London: Pinter Publishers.

Manacorda, M. and Moretti, E. (2006), "Why Do Most Italian Youths Live with Their Parents? Intergenerational Transfers and Household Structure." Journal of the European Economic Association 4(4): 800-829.

Moreno, R., Paci, R and Usai, S. (2005a) "Spatial Spillovers and Innovation Activity in European Regions", Environment and planning A 37: 1973-1812

Moreno, R., Paci, R., Usai, S. (2005b) "Geographical and sectoral clusters of innovation in Europe”, Annals of Regional Science, 39: 715-739.

Morgan, K., (1997),'The Learning Region: Institutions, Innovation and Regional Renewal", Regional Studies 31: 491-504.

Nannicini, T., Stella, A., Tabellini G., Troiano U. (2010), "Social Capital and Political Accountability", Università Bocconi, mimeo.

Nuzzo, G. (2006) "Un Secolo di Statistiche Sociali: Persistenza o Convergenza tra le regioni Italiane?", Quaderni dell'Ufficio Ricerche Storiche, 11 - Bank of Italy

O'hUallachain, B. and Leslie, T.F. (2007) "Rethinking the regional knowledge production function", Journal of Economic Geography, 7(6): 737-752.

OECD (2001) Using patent counts for cross-country comparisons of technology output. STI Review, 27: 129-146.

Olson, M., (1982), The rise and decline of nations: Economic growth, stagflation, and social rigidities, Yale University Press, New Heaven.

Patton, D. and Kenney, M., (2003) "Innovation and social capital in Silicon Valley", BRIE Working Paper 155, Berkeley, CA. 
Percoco, M. (2010a), "Path dependence, institutions and the density of economic activities" FEE; Working Paper 499

Percoco, M (2020b) "Enterpreneurship and social capital:evidence from Italian cities" Spatial Economic Analysis, fortcoming.

Ponds, R, van Oort, F. and Frenken, K. (2010), "Innovation, spillovers and universityindustry collaboration: an extended knowledge production function approach", Journal of Economic Geography, 10(2): 231-255

Portes, A., and Landolt, P., (1996), "The downside of social capital”, The American Prospect, 94(26): 18-21.

Putnam, R. D., (1993), Making Democracy Work: Civic Traditions in Modern Italy, Princeton: Princeton University Press.

Putnam, R. D., (2000), "Bowling alone. The collapse and revival of American community”, New York: Simon \& Schuster.

Ramella, F. and Trigilia, C. (2009) "Le Strategie dell'Innovazione. Indagine sui Brevetti Europei delle Imprese Italiane”, Economia e Politica Industriale, 36(2): 199213

Ramella, F. and Trigilia, C., (2010), "Legami forti e deboli nella costruzione sociale delle invenzioni”, Stato e Mercato, 88 (April): 78-102.

Reher, D.S. 1998. "Family Ties in Western Europe: Persistent Contrasts." Population and Development Review 24(2): 203-234.

Rodríguez-Pose, A., (1999), "Innovation prone and innovation averse societies: economic performance in Europe", Growth and Change, 30: 75-105.

Rodríguez-Pose A. and Crescenzi R. (2008) "R\&D, spillovers, innovation systems and the genesis of regional growth in Europe” Regional Studies, 42(1): 51-67

Rodríguez-Pose, A. and Storper, M., (2006), "Better rules or stronger communities? On the social foundations of institutional change and its economic effects", Economic Geography, 82(1): 1-25.

Rogers, E. M., (1995), Diffusion of innovations (4th ed.). New York: The Free Press.

Ruef, M., (2002), "Strong Ties, Weak Ties and Islands: Structural and Cultural Predictors of Organizational Innovation.” Industrial and Corporate Change 11: 427-49.

Sabatini, F (2009), "Il Capitale Sociale nelle Regioni Italiane: un'Analisi Comparata" Rivista di Politica Economica 99: 167-220. 
Schuller, T., Baron, S., \& Field, J. (2000), "Social capital: a review and critic" in S. Baron, J. Field, \& T. Schuller (Eds.). Social Capital. Oxford: Oxford University Press.

Sedgley, N. and Elmslie, B. (2004) The geographic concentration of knowledge: scale, agglomeration and congestion in innovation acress U.S. states. International Regional Science Review, 27: 111-137.

Solow, R., (1999), "Notes on Social Capital and Economic Performance," in Dasgupta and Serageldin, eds. Social Capital: A Multifaceted Perspective, Washington: The World Bank.

Staiger, D., Stock, J.H., (1997), "Instrumental variables regression with weak instruments", Econometrica 65: 557-586.

Stock, J.H., Yogo, M.,( 2005), “Testing for weak instruments in linear IV regression". In: Stock, J.H., Andrews, D.W.K., (Eds.), Identification and Inference for Econometric Models: A Festschrift in Honour of Thomas Rothenberg. Cambridge University Press, Cambridge: 80-108. (Ch. 5).

Storper, M. (2005) "Society, community and economic development", Studies in Comparative Economic Development, 39(4): 30-57.

Tabellini, G (2010), "Culture and Institutions: Economic Development in the Regions of Europe" Journal of the European Economic Association, 8(4): 677-716

Tomassini (1999), Il Mutualismo nell'Italia liberale (1861-1922), Ministero per i Beni e le Attività Culturali, Le società di mutuo soccorso in Italia e i loro archivi, Rome: Ministero per le Attività ed i Beni Culturali.

Tura, T. and Harmaakorpi, V., (2005), " Social capital in building regional innovative capability”, Regional Studies 39: 1111-1125.

Varga, A., (1998), University Research and Regional Innovation, Boston: Kluwer Academic Publishers.

Woolcock, M., (1998), "Social Capital and Economic Development: Toward a Theoretical Synthesis and Policy Framework." Theory and Society 27(2): 151-20. 


\section{Appendix A - Variables included in the analysis}

Table A-1: Variables List

\begin{tabular}{|c|c|c|c|c|}
\hline VARIABLES & & DESCRIPTION & SOURCE & YEAR \\
\hline $\begin{array}{l}\text { Patents } \\
\text { Growth }\end{array}$ & $\begin{array}{l}\text { Logarithmic } \\
\text { applications } \\
\text { two extreme: }\end{array}$ & $\begin{array}{l}\text { insformation of the ratio of patent } \\
\text { ar million inhabitants in region } i \text { at the } \\
\text { of the period of analysis }(\mathrm{t}-\mathrm{T}, \mathrm{t})\end{array}$ & $\begin{array}{l}\text { OECD } \\
\text { RegPat database }\end{array}$ & $2001-2007$ \\
\hline $\begin{array}{l}\text { Patents } \\
\text { (Level in } \\
2001)\end{array}$ & $\begin{array}{l}\text { Logarithm of } \\
\text { inhabitants a } \\
\text { T) }\end{array}$ & $\begin{array}{l}\text { he level of patent applications per million } \\
\text { he beginning of the period of analysis (t- }\end{array}$ & $\begin{array}{l}\text { OECD } \\
\text { RegPat database }\end{array}$ & 2001 \\
\hline Private $\mathrm{R} \& \mathrm{D}$ & $\begin{array}{l}\text { Logarithm o } \\
\text { percentage c }\end{array}$ & $\begin{array}{l}\text { private expenditure in } \mathrm{R} \& \mathrm{D} \text { as } \\
\text { regional GDP at (t-T) }\end{array}$ & $\begin{array}{l}\text { ISTAT } \\
\text { Indicatori Ricerca e } \\
\text { Innovazione }\end{array}$ & 2001 \\
\hline Graduates & $\begin{array}{l}\text { Logarithm o } \\
\text { population a }\end{array}$ & $\begin{array}{l}\text { the number of graduates in over } 24 \\
\text { time }(\mathrm{t}-\mathrm{T})\end{array}$ & \begin{tabular}{|l} 
EUROSTAT \\
Regional Database \\
\end{tabular} & 2001 \\
\hline \begin{tabular}{|l} 
Female \\
Unemployme \\
nt
\end{tabular} & $\begin{array}{l}\text { Logarithm of } \\
\text { female labou }\end{array}$ & $\begin{array}{l}\text { orce number of unemployed women in total } \\
\text { orce }\end{array}$ & $\begin{array}{l}\text { OECD } \\
\text { Regional Database - } \\
\text { Regional Labour Market } \\
\text { TL3 database }\end{array}$ & 2001 \\
\hline $\begin{array}{l}\text { Sectoral } \\
\text { Shares and } \\
\text { Herfindal } \\
\text { Index }\end{array}$ & $\begin{array}{l}\text { Sector emplo } \\
\text { agriculture, ir } \\
\text { the Sum of th }\end{array}$ & $\begin{array}{l}\text { nent/total employment ratio defined for } \\
\text { ustry and services. Herfindal calculated as } \\
\text { square of these ratios. }\end{array}$ & $\begin{array}{l}\text { OECD - Regional Database } \\
\text { Regional Labour Market } \\
\text { TL3 dataset }\end{array}$ & 2001 \\
\hline $\begin{array}{l}\text { Population } \\
\text { density }\end{array}$ & Logarithm of & e population in respect to local surface & $\begin{array}{l}\text { OECD Regional Database - } \\
\text { Demographic Statistics TL3 } \\
\text { dataset }\end{array}$ & 2001 \\
\hline \multirow{4}{*}{ Social Capital } & \multirow[b]{2}{*}{ BRIDGING } & $\begin{array}{l}\text { Blood donations (Number of blood } \\
\text { donations per } 100 \text { residents) }\end{array}$ & Cartocci (2007) & 2001 \\
\hline & & $\begin{array}{l}\text { Voluntary Associations (Number of } \\
\text { voluntary associations per Kmq) }\end{array}$ & Cartocci (2007) & 2001 \\
\hline & \multirow[t]{2}{*}{ BONDING } & $\begin{array}{l}\text { Weekly Lunch (Number of families } \\
\text { having lunch at least once per week with } \\
\text { relatives and close friends per } 100 \\
\text { households) }\end{array}$ & $\begin{array}{l}\text { ISTAT } \\
\text { Rilevazione "Parentela e } \\
\text { Reti di solidarietà" }\end{array}$ & 2001 \\
\hline & & $\begin{array}{l}\text { Adult Children (Number of young adult } \\
\text { individuals living with parents per } 100 \\
\text { young adults) }\end{array}$ & $\begin{array}{l}\text { ISTAT } \\
\text { Rilevazione "Parentela e } \\
\text { Reti di solidarietà" } \\
\end{array}$ & 2001 \\
\hline Referendum & $\begin{array}{l}\text { Instrumental } \\
\text { Variable } \\
\text { (Bridging) }\end{array}$ & $\begin{array}{l}\text { Logarithm of the average political } \\
\text { participation to the following referenda: } \\
1946 \text { (Monarchy vs. Republic), } 1974 \\
\text { (divorce), } 1978 \text { and } 1981 \text { (abortion), } 1985 \\
\text { ('scala mobile') and } 1987 \text { (nuclear power) }\end{array}$ & Nuzzo (2006) & \begin{tabular}{|c|}
$1946-1974-$ \\
$1978-1981-$ \\
$1985-1987$ \\
(Mean \\
value) \\
\end{tabular} \\
\hline $\begin{array}{l}\text { Mutual } \\
\text { Organizations } \\
1911\end{array}$ & $\begin{array}{l}\text { Instrumental } \\
\text { Variable } \\
\text { (Bonding) }\end{array}$ & $\begin{array}{l}\text { Number of mutual organizations in } 1911 \\
\text { per } 100 \text { inhabitants }\end{array}$ & Nuzzo (2006) & 1911 \\
\hline
\end{tabular}


Fig.1: Social Capital (Total)

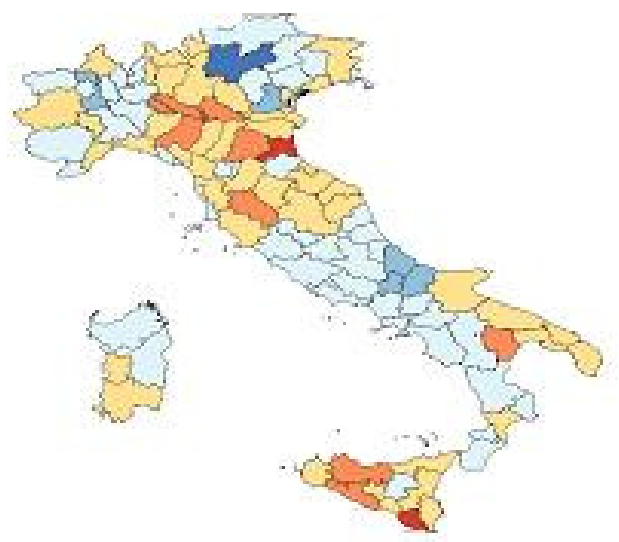

Fig.3: Bonding Social Capital

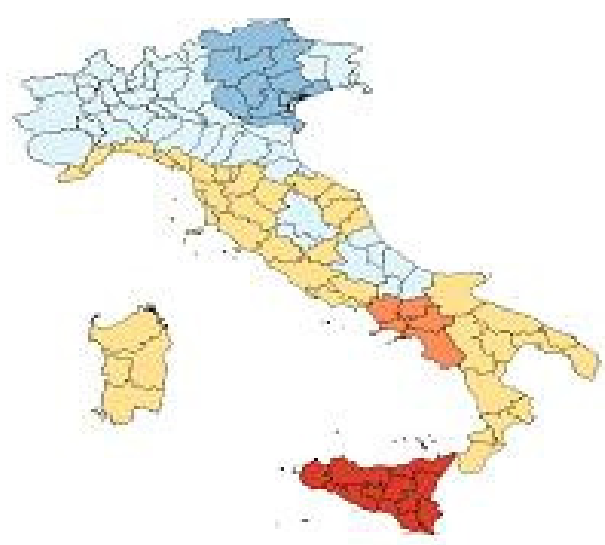

Fig 2: Bridging Social Capital

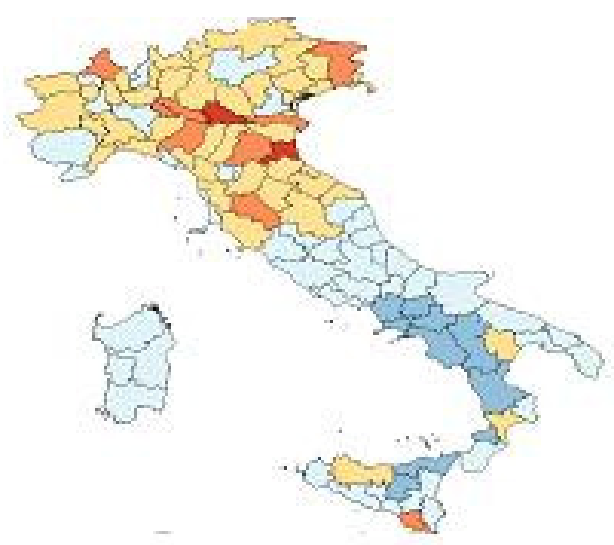

Fig.4: Innovation

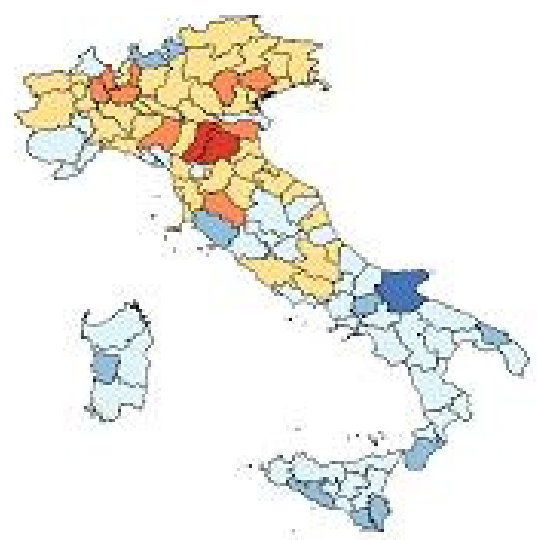

Legenda:

$<1 \%(0)$
$1 \%-10 \%(9)$
$10 \%-50 \%(42)$
$50 \%-90 \%(41)$
$90 \%-99 \%(2)$
$=99 \%(9)$

Note: Figures 1,2,3 and 4 report the percentile map for the level of patents in 2001, the composite measure of social capital in 2001, the measure for bonding and bridging social capital in 2001 respectively. 
Table 1: Descriptive Statistics

\begin{tabular}{|c|c|c|c|c|c|c|}
\hline Macroregion & Variable & Obs & Mean & Std. Dev. & Min & Max \\
\hline & Patents Growth & 45 & 0.0601 & 0.0633 & -0.1137 & 0.2377 \\
\cline { 2 - 7 } & $\begin{array}{c}\text { TOTAL Social } \\
\text { Capital }\end{array}$ & 46 & 0.3443 & 0.1718 & 0 & 0.8528 \\
\cline { 2 - 7 } NORTH & $\begin{array}{c}\text { Bonding Social } \\
\text { Capital }\end{array}$ & 46 & 0.2467 & 0.1091 & 0 & 0.5100 \\
\cline { 2 - 7 } & $\begin{array}{c}\text { Bridging Social } \\
\text { Capital }\end{array}$ & 46 & 0.4922 & 0.1679 & 0.1867 & 1 \\
\hline \multirow{5}{*}{ CENTRE } & Patents Growth & 24 & 0.0581 & 0.0680 & -0.0724 & 0.2002 \\
\cline { 2 - 7 } & $\begin{array}{c}\text { TOTAL Social } \\
\text { Capital }\end{array}$ & 25 & 0.3112 & 0.1383 & 0.1101 & 0.6568 \\
\cline { 2 - 7 } & $\begin{array}{c}\text { Bonding Social } \\
\text { Capital }\end{array}$ & 25 & 0.4759 & 0.0339 & 0.4322 & 0.5377 \\
\cline { 2 - 7 } & $\begin{array}{c}\text { Bridging Social } \\
\text { Capital }\end{array}$ & 25 & 0.3344 & 0.1262 & 0.1620 & 0.6667 \\
\hline & Patents Growth & 28 & 0.0388 & 0.1415 & -0.2073 & 0.3393 \\
\cline { 2 - 7 } & $\begin{array}{c}\text { TOTAL Social } \\
\text { Capital }\end{array}$ & 32 & 0.3611 & 0.1905 & 0.0735 & 1 \\
\cline { 2 - 7 } & $\begin{array}{c}\text { Bonding Social } \\
\text { Capital }\end{array}$ & 32 & 0.8463 & 0.1424 & 0.4271 & 1 \\
\cline { 2 - 7 } & $\begin{array}{c}\text { Bridging Social } \\
\text { Capital }\end{array}$ & 32 & 0.1801 & 0.1649 & 0 & 0.7196 \\
\hline
\end{tabular}

Table 2: Correlation Matrix

\begin{tabular}{|c|c|c|c|}
\hline & Patents Growth & Social Capital & Bonding \\
\hline TOTAL Social Capital & 0.2408 & & \\
\hline Bonding Social Capital & -0.0143 & 0.1649 & \\
\hline Bridging Social Capital & 0.1936 & 0.6812 & -0.6097 \\
\hline
\end{tabular}


Table 3: Estimation of the Empirical Model: Regional Knowledge Production Function with Total, Bonding and Bridging Social Capital: Annual growth rate of regional patenting (2001-2007)

Dep. Var.: Patent growth Patents

(level in 2001)

Private R\&D

Graduates

Female unemployment

Employment in agriculture

Employment in services

Population density

Spatial lag of population density

Total social capital endowment

Spatial lag of total social capital

Bonding social capital

Bridging social capital

North

Centre

\section{Constant}

Observations

$\mathrm{R}$-squared

$* * * \mathrm{p}<0.01, * * \mathrm{p}<0.05, * \mathrm{p}<0.1$ - Clustered - robust standard errors in parentheses
2SLS

$-0.0875 * * *$

(0.0107)

0.00350

$(0.0149)$

0.0256

$(0.0640)$

$-0.00302$

(0.00664)

$-0.0612$

(0.0384)

$0.0432 * * *$

$(0.00792)$

$-0.0195$

(0.0136)

(0.0213)

$0.114 * *$

$(0.0517)$

$0.146^{* *}$

(0.0652)

$-0.0208$

(0.126)

$\begin{array}{cc}-0.0201 & -0.0514 \\ (0.102) & (0.0942) \\ 0.165 * * * & 0.392 * * * \\ (0.0515) & (0.0652) \\ 0.110 & 0.0296 \\ (0.0727) & (0.0779) \\ 0.102 * * & 0.0636 \\ (0.0469) & (0.0525) \\ 0.202 & 0.0619 \\ (0.232) & (0.214) \\ 97 & 97 \\ 0.434 & 0.313\end{array}$


Table 4: First stage regressions

(1)

(2)

Dep.Var.:

Bonding social capital Bridging social capital

\begin{tabular}{lcc}
\hline Patents & -0.0219 & 0.00238 \\
(level in 2001) & $(0.0207)$ & $(0.0243)$ \\
Private R\&D & $0.0633 * *$ & -0.0102 \\
& $(0.0286)$ & $(0.0239)$ \\
Graduates & 0.0376 & 0.0754 \\
& $(0.0323)$ & $(0.0801)$ \\
Female unemployment & -0.0030 & $0.0319 * *$ \\
& $(0.0090)$ & $(0.0142)$ \\
Employment in agriculture & 0.0008 & -0.0071 \\
& $(0.0068)$ & $(0.0086)$ \\
Employment in services & -0.0258 & 0.0861 \\
& $(0.0528)$ & $(0.0566)$ \\
Population density & 0.0245 & -0.0196 \\
& $(0.0145)$ & $(0.0149)$ \\
Spatial lag of population density & 0.0293 & -0.0079 \\
& $(0.0229)$ & $(0.0253)$ \\
Total social capital endowment & $-0.641 * * *$ & 0.0435 \\
& $(0.0750)$ & $(0.0886)$ \\
Spatial lag of total social capital & $-0.396 * * *$ & -0.0809 \\
& $(0.0591)$ & $(0.0775)$ \\
Referenda [Bridging] & -0.250 & $1.426 * * *$ \\
& $(0.268)$ & $(0.271)$ \\
Mutual organizations 1911 & $0.0008 * * *$ & -0.0001 \\
[Bonding] & $(0.0002)$ & $(0.0002)$ \\
Constant & 1.864 & $(1.335)$ \\
& $(1.177)$ & 97 \\
Observations & 97 & 0.619 \\
R-squared & 0.931 &
\end{tabular}

$* * * \mathrm{p}<0.01, * * \mathrm{p}<0.05, * \mathrm{p}<0.1$

Clustered - robust standard errors in parentheses

Table 5: First stage statistics

\begin{tabular}{|c|c|c|c|c|}
\hline Variable & Shea Partial R2 & Partial R2 & $\mathrm{F}(2,19)$ & P-value \\
\hline $\begin{array}{c}\text { Bridging Social } \\
\text { Capital }\end{array}$ & 0.1773 & 0.1997 & 14.19 & 0.0002 \\
\hline $\begin{array}{c}\text { Bonding Social } \\
\text { Capital }\end{array}$ & 0.2920 & 0.3289 & 6.31 & 0.0079 \\
\hline
\end{tabular}


Table 6: Robustness Checks (1): Estimation of the Empirical Model: Regional Knowledge Production Function with Bonding and Bridging Social Capital: Level of Patents $(2002,2005,2007)$

(1) (2) (3)

Patents Patents Patents

Dep.Var.:

(Level in 2002)

(Level in 2005) (Level in 2007)

Bonding social capital

(0.956)

$-1.099$

$-1.445$

$2.173^{* *}$

$(0.886)$

$(0.882)$

Bridging social capital

(0.977)

$-0.0536$

$3.017 * * *$

$3.016^{* * *}$

Private $R \& D$

(0.119)

(0.956)

(0.518)

$-0.0164$

0.0423

Graduates

0.416

(0.144)

(0.141)

(0.337)

$-0.483$

0.0513

0.0833

(0.0748)

0.0235

$(0.0924)$

0.0762

(0.370)

(0.306)

(0.492)

Female unemployment

$0.311 * * *$

(0.0909)

0.101

(0.204)

0.138

(0.710)

$-0.114$

$-0.0820$

(0.0873)

(0.100)

0.0854

(0.0619)

0.0335

$(0.0624)$

$-0.0480$

$-0.349$

$(0.288)$

(0.324)

Population density

0.446

(0.490)

2.505

(1.927)

$0.308 * * *$

(0.0770)

$0.410 * * *$

(0.0589)

$-0.165$

$-0.109$

(0.107)

0.231

0.475

(0.715)

(0.736)

0.596

0.598

(0.517)

(0.492)

0.527

(1.599)

0.942

(1.782)

97

0.696

103

103

0.668

0.710

$* * * \mathrm{p}<0.01, * * \mathrm{p}<0.05, * \mathrm{p}<0.1$

Clustered - robust standard errors in parentheses 
Table 7: Robustness Checks (2): Estimation of the Empirical Model: Regional Knowledge Production Function with Bonding and Bridging Social Capital: Annual growth rate of regional patenting (2001-2007)

\begin{tabular}{|c|c|c|c|c|c|c|}
\hline & (1) & (2) & (3) & (4) & (5) & (6) \\
\hline Dep.Var.: Patent Growth & 2SLS & 2 SLS & 2SLS & 2SLS & 2 SLS & 2SLS \\
\hline \multirow[t]{2}{*}{ Bonding Social Capital } & -0.0514 & -0.0632 & -0.0716 & -0.0718 & -0.0648 & -0.0417 \\
\hline & $(0.0942)$ & $(0.158)$ & $(0.153)$ & $(0.154)$ & $(0.152)$ & $(0.111)$ \\
\hline Bridging Social Capital & $\begin{array}{c}0.392 * * * \\
(0.0652)\end{array}$ & $\begin{array}{c}0.388 * * * \\
(0.0914)\end{array}$ & $\begin{array}{c}0.398 * * * \\
(0.0917)\end{array}$ & $\begin{array}{c}0.398 * * * \\
(0.0906)\end{array}$ & $\begin{array}{c}0.394 * * * \\
(0.0902)\end{array}$ & $\begin{array}{c}0.410 * * * \\
(0.0874)\end{array}$ \\
\hline \multirow[t]{2}{*}{ Patents (level in 2001) } & $-0.0875 * * *$ & $-0.0833 * * *$ & $-0.0849 * * *$ & $-0.0851 * * *$ & $-0.0841 * * *$ & $-0.0849 * * *$ \\
\hline & $(0.0107)$ & $(0.0107)$ & $(0.0128)$ & $(0.0126)$ & $(0.0131)$ & $(0.0134)$ \\
\hline \multirow[t]{2}{*}{ Private $R \& D$} & 0.0035 & 0.0134 & 0.0135 & 0.0134 & 0.0144 & \\
\hline & $(0.0149)$ & $(0.0230)$ & $(0.0242)$ & $(0.0242)$ & $(0.0241)$ & \\
\hline \multirow[t]{2}{*}{ Graduates } & 0.0256 & 0.0481 & -0.0252 & -0.0268 & & \\
\hline & $(0.0640)$ & $(0.0712)$ & $(0.0571)$ & $(0.0535)$ & & \\
\hline \multirow[t]{2}{*}{ Female unemployment } & -0.0030 & -0.0036 & 0.0021 & & & \\
\hline & $(0.0127)$ & $(0.0135)$ & $(0.0136)$ & & & \\
\hline Employment in agriculture & 0.0037 & 0.0030 & & & & \\
\hline \multirow{2}{*}{ Employment in services } & -0.0612 & $-0.0940 * * *$ & & & & \\
\hline & $(0.0384)$ & $(0.0362)$ & & & & \\
\hline Population density & $0.0432 * * *$ & & & & & \\
\hline \multirow[t]{2}{*}{ Spatial lag of population density } & -0.0195 & & & & & \\
\hline & $(0.0136)$ & & & & & \\
\hline North & $\begin{array}{l}0.0296 \\
(0.0779)\end{array}$ & $\begin{array}{l}0.0051 \\
(0.136)\end{array}$ & $\begin{array}{r}-0.0019 \\
(0.135)\end{array}$ & $\begin{array}{l}-0.0017 \\
(0.135)\end{array}$ & $\begin{array}{l}-0.0018 \\
(0.134)\end{array}$ & $\begin{array}{l}0.0333 \\
(0.0794)\end{array}$ \\
\hline \multirow[t]{2}{*}{ Centre } & 0.0636 & 0.0461 & 0.0422 & 0.0422 & 0.0399 & 0.0634 \\
\hline & $(0.0525)$ & $(0.0882)$ & $(0.0877)$ & $(0.0878)$ & $(0.0877)$ & $(0.0528)$ \\
\hline \multirow[t]{2}{*}{ Constant } & 0.0619 & 0.221 & 0.143 & 0.135 & 0.206 & 0.154 \\
\hline & $(0.214)$ & $(0.277)$ & $(0.253)$ & $(0.241)$ & $(0.184)$ & $(0.105)$ \\
\hline Observations & 97 & 97 & 97 & 97 & 97 & 97 \\
\hline R-squared & 0.313 & 0.222 & 0.171 & 0.171 & 0.175 & 0.151 \\
\hline
\end{tabular}

$* * * \mathrm{p}<0.01, * * \mathrm{p}<0.05, * \mathrm{p}<0.1$ - Clustered - robust standard errors in parentheses 
Table 8: Robustness Checks (3): Reduced Form equation

(1) (2)

Dep.Var.: Patents Growth OLS OLS

\begin{tabular}{|c|c|c|}
\hline$\overline{\text { Patents }}$ & $-0.0797 * * *$ & $-0.0851 * * *$ \\
\hline (Level in 2001) & $(0.0119)$ & $(0.0104)$ \\
\hline Private $R \& D$ & $\begin{array}{l}0.00168 \\
(0.0119)\end{array}$ & $\begin{array}{c}-0.0032 \\
(0.0118)\end{array}$ \\
\hline Graduates & $\begin{array}{c}0.0513 \\
(0.0684)\end{array}$ & $\begin{array}{c}0.0555 \\
(0.0590)\end{array}$ \\
\hline Female unemployment & $\begin{array}{l}0.00387 \\
(0.0125)\end{array}$ & $\begin{array}{l}0.00956 \\
(0.0112)\end{array}$ \\
\hline Employment in agriculture & $\begin{array}{c}0.0025 \\
(0.00686)\end{array}$ & $\begin{array}{l}0.000974 \\
(0.00744)\end{array}$ \\
\hline Employment in services & $\begin{array}{c}-0.0439 \\
(0.0420)\end{array}$ & $\begin{array}{c}-0.0274 \\
(0.0442)\end{array}$ \\
\hline Population density & $\begin{array}{c}0.0381 * * * \\
(0.0106)\end{array}$ & $\begin{array}{c}0.0339 * * * \\
(0.0114)\end{array}$ \\
\hline Spatial lag of population density & $\begin{array}{l}-0.0234 \\
(0.0168)\end{array}$ & $\begin{array}{l}-0.0235 \\
(0.0144)\end{array}$ \\
\hline Bonding social capital & $\begin{array}{r}-0.0201 \\
(0.102)\end{array}$ & \\
\hline Bridging social capital & $\begin{array}{c}0.165 * * * \\
(0.0515)\end{array}$ & \\
\hline Mutual organizations in 1911 [Bonding] & & $\begin{array}{c}-0.0088 \\
(0.00981)\end{array}$ \\
\hline Referenda [Bridging] & & $\begin{array}{c}0.579 * * * \\
(0.111)\end{array}$ \\
\hline North & $\begin{array}{c}0.110 \\
(0.0727)\end{array}$ & $\begin{array}{l}0.0748^{*} \\
(0.0423)\end{array}$ \\
\hline Centre & $\begin{array}{l}0.102 * * \\
(0.0469)\end{array}$ & $\begin{array}{c}0.0490 \\
(0.0364)\end{array}$ \\
\hline Constant & $\begin{array}{c}0.202 \\
(0.232)\end{array}$ & $\begin{array}{c}-2.277 * * * \\
(0.479)\end{array}$ \\
\hline Observations & 97 & 97 \\
\hline R-squared & 0.434 & 0.448 \\
\hline
\end{tabular}

